\title{
True Mangrove Species of Sundarbans Delta, West Bengal, Eastern India
}

\author{
Jyotiskona Barik ${ }^{1^{*}}$ and Soumyajit Chowdhury ${ }^{2}$ \\ 1 School of Oceanographic Studies, Jadavpur University, Kolkata - 700032, West Bengal, India. \\ 2 Centre for Biodiversity and Ecological Studies, Kolkata - 700 084, West Bengal, India. \\ * Corresponding Author. E-mail: bjyotiskona@gmail.com
}

\begin{abstract}
Varied opinions exist as to the species composition and ecological distinction of mangrove habitats of the Indian Sundarbans. Furthermore, distinction of true or major mangroves from mangrove-associate and minor species was left unresolved by past authors. The present study thus aimed to revise a species list of true mangroves in the Indian Sundarbans delta. An indexing of adaptive morpho-physiological characters of mangroves for the tidal-saline environment was conducted. The analysis illustrated 24 species of true mangroves in Indian Sundarbans, belonging to nine families. Of these, Rhizophoraceae showed maximum richness at each of the generic and specific categories assessed. The current study has highlighted the taxonomic richness and status of true mangrove from Indian Sundarbans, resolving the long debated distinction of true from minor and associate mangroves.
\end{abstract}

\section{INTRODUCTION}

The Sundarbans delta is a rich reservoir of flora and fauna due to its extremely dynamic physico-chemical factors. Encompassing India and Bangladesh, this highly dynamic zone supports a diverse gene pool of micro and macro biotic communities, in which mangrove vegetation occupies a special status (Guha Bakshi et al., 1998). The Sundarbans mangrove ecosystem is highly productive and serves as a link between terrestrial and estuarine aquatic ecosystems (Untawale, 1987).

Mangroves are a threatened salt tolerant higher group of flowering plants (Naskar and Mandal, 1999) that occur in relatively sheltered areas along estuaries, coastal lagoons and backwaters. They are generally inundated and exposed during regular high and low tides respectively, and are nurtured by a mixture of fresh water from rains and land drainage with coastal marine waters (Banerjee et al. 2002). The plants of mangrove vegetation are relatively poor in species diversity and show similarities in their general architecture and physiological adaptations - a case of convergent evolution. Typical mangrove species usually have pneumatophores or breathing roots (negative geotropic root), stilt roots, knee roots, viviparous germination, xerophyllous leaves and salt excretory glands (Tomlinson, 1986). However, several mangrove workers like Mac Nae (1968), Blasco (1977), Mepham and Mepham (1984), Tomlinson (1986), Naskar and Guha Bakshi (1987) defined mangroves emphasizing on different eco-physiological attributes. Different approaches were adopted in the process towards classifying the mangrove species in different mangrove areas of India, including the Indian Sundarbans delta.

Regarding the species composition and ecological distinction of mangrove flora in the Indian Sundarbans, several authors opined variedly; viz. 60 species under 41 genera and 29 families (Rao 1986), 56 species of euryhaline mangrove and mangrove associates (Naskar and Guha Bakshi 1987) and 69 species under 49 genera and 35 families Mandal and Naskar (2008). Further ambiguity exists regarding the distinction of major or true mangroves from minor and mangrove-associated species, particularly at their generic levels. Mandal and Nandi (1989) reported 22 true mangroves species from Indian Sundarbans, while Chaudhuri and Choudhury (1994) reported 36 species. The studies of Naskar (1983) and Naskar and Mandal (1999) did not clarify this issue, as they remained uncertain regarding the exact status and composition of true or major mangroves in Indian Sundarbans. However, according to recent studies by Mandal and Naskar (2008), 28 species of major mangroves have been found in Indian Sundarbans. The study also mentioned Indian Sundarbans to be more diverse in its species composition than the other mangrove formations in India.

In the present context, the authors seek to revise the species list of the true or major mangroves occurring in Indian Sundarbans, taking into consideration their morpho-physiological characters for adapting to the tidalsaline environment in this deltaic region.

\section{MATERIALS AND Methods \\ Study Area}

The Indian Sundarbans $\left(21^{\circ} 31^{\prime} 00^{\prime \prime} \mathrm{N}-22^{\circ} 30^{\prime} 00^{\prime \prime} \mathrm{N}\right.$, $88^{\circ} 10^{\prime} 00^{\prime \prime} \mathrm{E}-89^{\circ} 51^{\prime} 00^{\prime \prime} \mathrm{E}$ ) is located on the southern fringe on the state of West Bengal spreading over the major portion of the districts of North 24-Parganas and South 24-Parganas. The region is bordered by Harinbhanga-Raimangal river along the International boundary with Bangladesh in the east, the Hooghly River in the west, "Dampier- Hodges line" in the North and Bay of Bengal in the south. The Indian Sundarbans delta (declared as Sundarbans Biosphere Reserve under the 'Man and Biosphere Programme' in 1989) covers an area of $9,630 \mathrm{~km}^{2}$ (Naskar and Mandal 1999) (Figure 1). Of the 102 islands in the estuary, 54 are inhabited and the rest of the islands support mangrove forests (Chaudhuri and Choudhury 1994). The mangrove forests of the Indian 


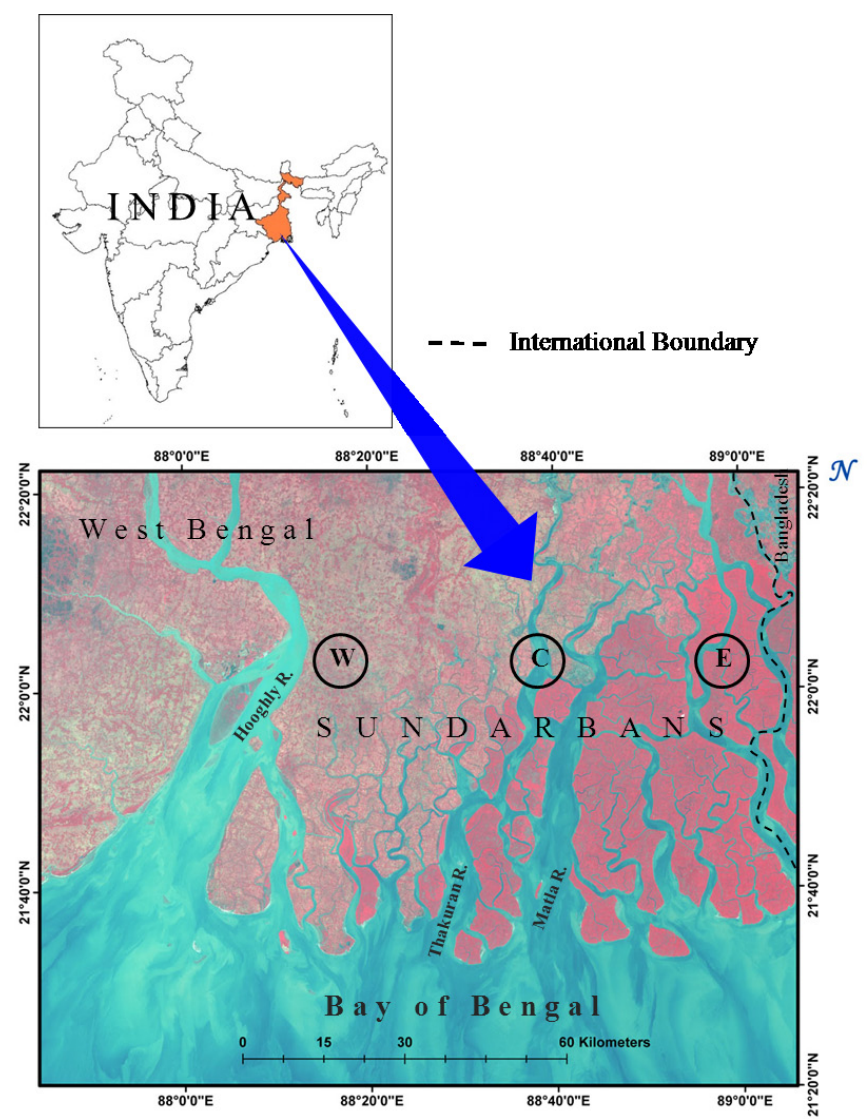

FIGURE 1. A satellite image of India Sundarbans; W, C and E represent Western, Central and Eastern parts of Indian Sundarbans under the present study.
Sundarbans have been estimated between 418, 888 ha. (UNEP 1985 (unpublished data)), 200,000-300,000 ha. (IUCN 1989) and 6,749 $\mathrm{km}^{2}$ (Naskar and Mandal 1999). The discrepancy in the figures for forest cover possibly arises from the fact that some analyses denote areas designated as forest lands (e.g. including waterways and degraded forest) while others represent an assessment of the tree-covered areas only (Chaudhuri and Choudhury 1994).

\section{Methodology}

The present work is a species list for the true mangroves in Indian Sundarbans, following a set of morpho-physiological features (Figure 2) as regard their adaptation in the saline-tidal zone. The authors incorporated both the previous works (as literature survey) as well as field surveys. Field surveys for two years: 2010 and 2011 involved sampling of mangrove flora in Eastern, Central and Western parts of the Sundarbans (Figure 1), taking into account the adaptive features considered in the present case for being true mangroves. The adaptive features considered here were followed after Tomlinson (1986). Voucher specimens were deposited in the Centre for Biodiversity and Ecological Studies, India. Identifications were carried out at the specific category by the authors in consultation with various mangrove specialists. IUCN statuses were taken from the IUCN Red List of Threatened Species, Version 2011.2 (2012).

\begin{tabular}{|c|c|c|c|c|c|c|c|c|c|}
\hline \multirow[b]{2}{*}{ 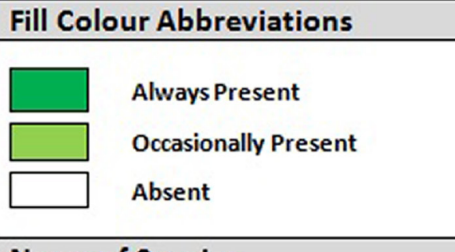 } & \multicolumn{9}{|c|}{ Characteristics } \\
\hline & 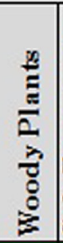 & 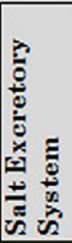 &  &  &  & 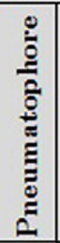 & 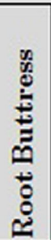 & 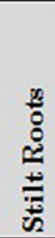 & 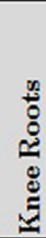 \\
\hline Bruguiera cylindrica & & & & & & & & & \\
\hline Bruguiera gymnorhiza & & & & & & & & & \\
\hline Bruguiera parviflora & & & & & & & & & \\
\hline Bruguiera sexangula & & & & & & & & & \\
\hline Ceriops decandra/roxburghiana & & & & & & & & & \\
\hline Ceriops tagal/candolleana & & & & & & & & & \\
\hline Rhizophora apiculata/conjugata & & & & & & & & & \\
\hline Rhizophora mucronata & & & & & & & & & \\
\hline Kandelia candel & & & & & & & & & \\
\hline Sonneratia apetala & & & & & & & & & \\
\hline Sonneratia caseolaris & & & & & & & & & \\
\hline Sonneratia griffithii & & & & & & & & & \\
\hline Lumnitzera racemosa & & & & & & & & & \\
\hline Xylocarpus granthum/carapa & & & & & & & & & \\
\hline Xylocarpus mekongensis & & & & & & & & & \\
\hline Aglaia cuculata & & & & & & & & & \\
\hline Avicennia alba & & & & & & & & & \\
\hline Avicennia marina & & & & & & & & & \\
\hline Avicennia officinalis & & & & & & & & & \\
\hline Aegialitis rotundifolia & & & & & & & & & \\
\hline Heritiera fomes & & & & & & & & & \\
\hline Aegiceras cormiculatum & & & & & & & & & \\
\hline Nypa fruticans & & & & & & & & & \\
\hline Phoenix paludosa & & & & & & & & & \\
\hline
\end{tabular}

FIGURE 2. Consideration of key morpho-physiological features for being true or major mangroves, with a list of species qualifying for major counterparts of Indian Sundarban mangroves. The list of species follows the same order as in Table 1. 


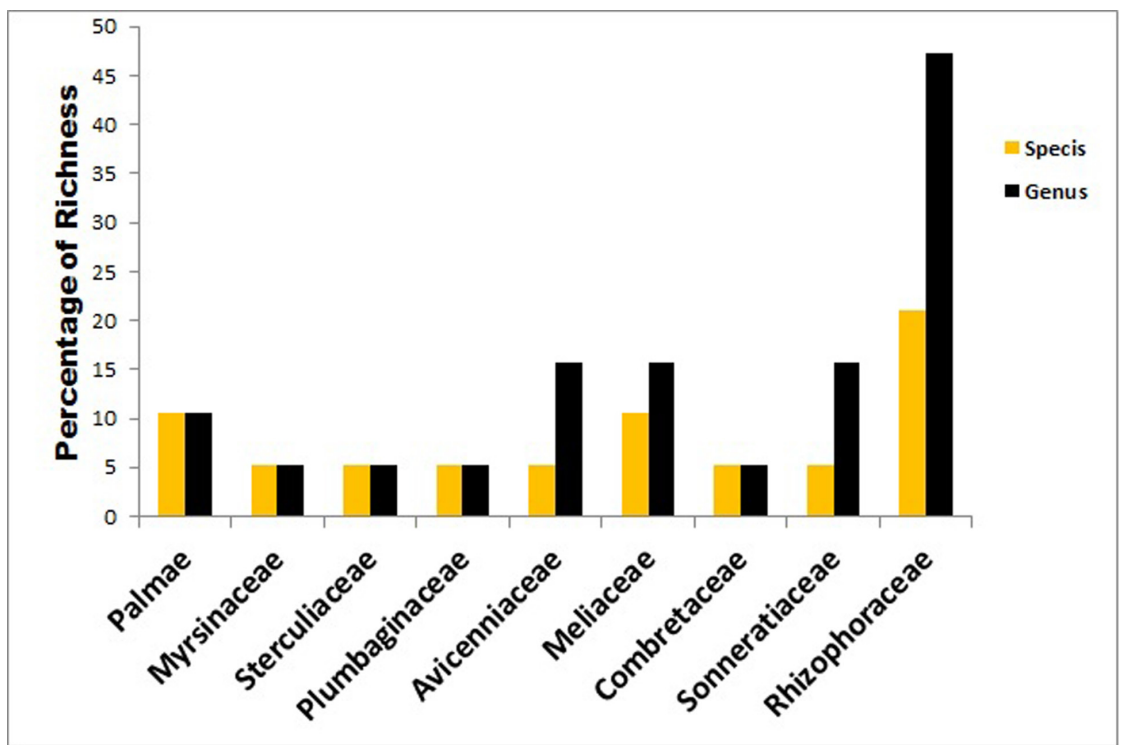

FIGURE 3. Graphical representation of the percentage of richness in genera and species of mangrove families in Indian Sundarbans pertaining to true mangroves.

\section{RESULTS}

Following the literature review and field survey, a total of 24 species of true or major mangroves were recorded in the Indian Sundarbans (Table 1 and Figure 2). The present species list comprises of nine species in four genera belonging to Rhizophoraceae family; three species in one genus to Sonneratiaceae; three species in one genus under Avicenniaceae; three species in two genera under Meliaceae; two species in two genera under Palmae/Arecaceae; and one species in one genus each under Combretaceae, Plumbaginaceae, Sterculiaceae and Myrcenaceae (Figure 3).

As the present article deals with species-level taxa of true mangroves in Indian Sundarbans, varieties of Avicennia marina Vierh., viz. A. marina var. marina (Forsk. Vierh) and A. marina var. acutissima Stapf. \& Mold. ex Mold., as proposed by Naskar and Mandal (1999) were hence excluded from the species list. Excoecaria agallocha Linn., a widely noted mangrove-associate or even a marginal species (Askornkeae et al. 1992) that has been included under the true mangroves by Mandal and Nandi (1989) and Naskar and Mandal (1999) has also been excluded in the present study. Besides, considering the salient characters (for being true mangroves) adopted here (Figures 2, 4 and 5), E. agallocha qualified only for two characters, by being woody in nature and having snake roots, which seemed inadequate to meet the criteria for being true mangroves, as also suggested by Askornkeae et al. (1992). Likewise, Porteresia coarctata (Roxb.) Takeoka, Acanthus ilicifolius (L.), A. volubilis Wall. and Scyphiphora hydrophyllacea Gaertn. F. are also mentioned as true mangroves by Mandal and Naskar (2008), but are here also excluded from the present list as they too did not qualify for most of the aforementioned characters. All these species, however, were found to have salt-tolerant mechanisms, but as mangrove-associates (Giesen et al. 2006; Sengupta and Lahiri Majumdar 2010).

of the nine families in Sundarbans, Rhizophoraceae shows the maximum richness in taxa at both genus and species level (Figure 3); this family, often referred to as the "true mangrove family" (Duke et al. 1998), shows the richest assemblage in most of the mangrove ecosystems of the world by having a myriad of adaptive specializations, as also evident in the present case of Sundarbans ecosystem (Figure 2). Features like stilt roots (Figure 5F) and viviparous germination in members of Rhizophoraceae in Sundarbans provide mechanical support towards substrate instability as well as increased survivability of saplings.

\section{DISCUSSION}

Mangrove ecosystems are threatened globally due to their widespread resources which are utilized for human use. In the Asia-Pacific region, non-sustainable utilization, overexploitation of resources and conversion to other land-uses principally for fish ponds, human settlements, infrastructure development and paddy cultivation are drastically reducing these resource bases at a very alarming rate (Umali et al. 1987). In Indian Sundarbans, the principal problems hindering sustainable management of the mangrove ecosystem is land acquisition by reclamation for settlement and expansion of agriculture resulting from population pressure (Burbridge 1984 (unpublished data)). Of the twenty-four true mangrove species in Sundarbans, five species are globally considered important regarding their conservation importance (IUCN, 2011). While Sonneratia griffithii Kurz. is critically endangered, Heritiera fomes Buch. Ham. (locally revered and called as Sundari) is considered endangered. The remaining three species, viz. Ceriops decandra Ding Hou, Aegialitis rotundifolia Roxb. and Phoenix paludosa Roxb. are near threatened. Sonneratia caseolaris Engler, however has not yet been enlisted in IUCN Red List (IUCN, 2011). The present study has illustrated an indexing system, and highlighted how the long debated distinction of true or major mangroves from minor and mangrove-associate species can be determined on common adaptive characters. It may further help in preparing or revising species lists of different mangroves, which in turn can support development of policy towards mangrove conservation in India. 


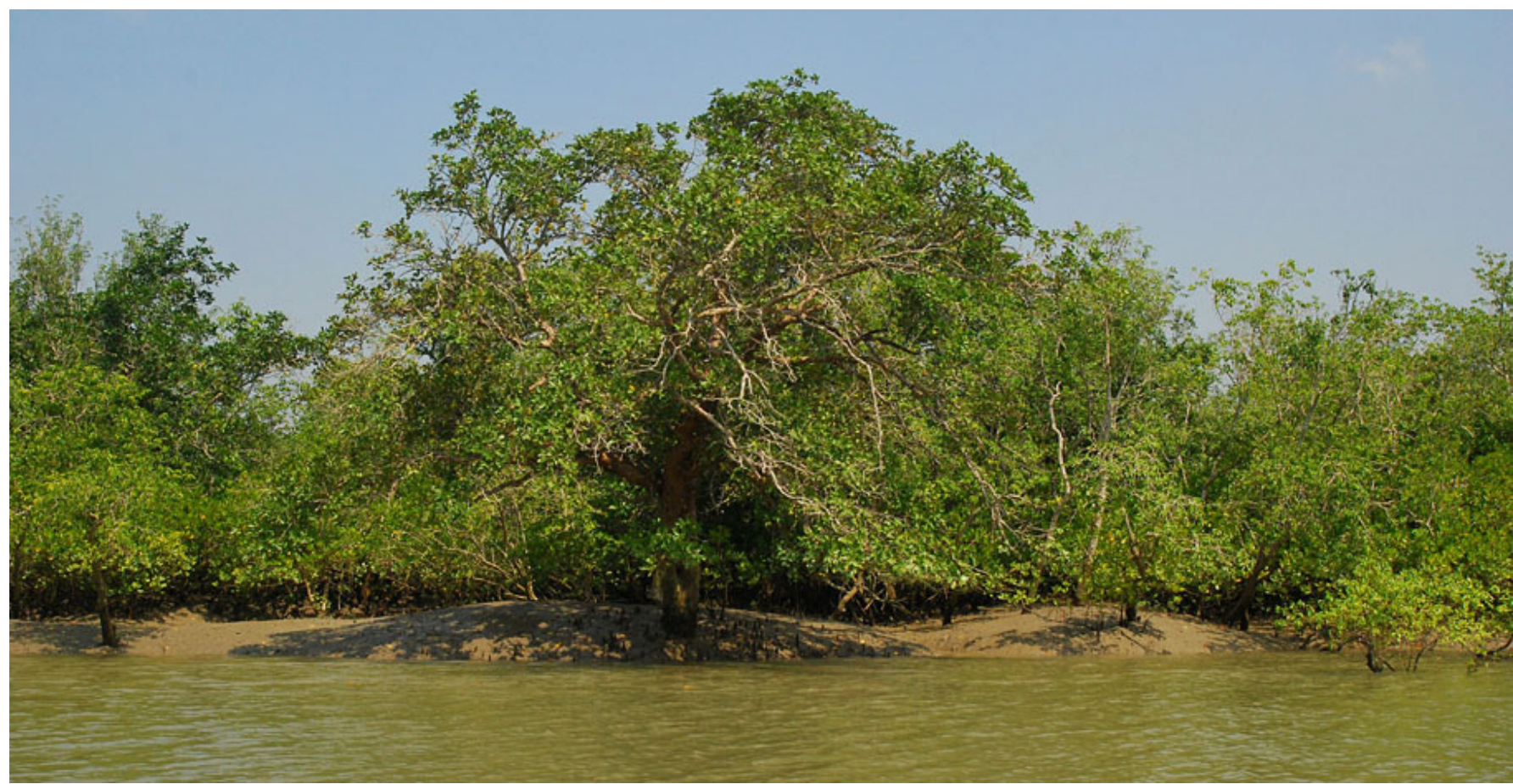

FIGURE 4. The mangrove forest of Indian Sundarbans, showing the woody nature of the true mangrove plants.

TABLE 1. A list of true mangrove species from Indian Sundarbans Region with their IUCN status.

\begin{tabular}{|c|c|c|c|c|}
\hline FAMILY & GENUS & SPECIES & VOUCHER NO. & IUCN STATUS \\
\hline \multirow{9}{*}{ Rhizophoraceae } & \multirow{4}{*}{ Bruguiera } & cylindrica Blume & CBES403 & Least Concern \\
\hline & & gymnorhiza Lamk. & CBES456 & Least Concern \\
\hline & & parviflora Wt. and Arn. & CBES459 & Least Concern \\
\hline & & sexangula Poir & CBES460 & Least Concern \\
\hline & \multirow{2}{*}{ Ceriops } & decandra Ding Hou /roxburghiana Arn. & CBES471 & Near Threatened \\
\hline & & tagal Robinson/candolleana Robinson & CBES472 & Least Concern \\
\hline & \multirow{2}{*}{ Rhizophora } & apiculata Blume/conjugata Arn. & CBES507 & Least Concern \\
\hline & & mucronata Lamk. & CBES549 & Least Concern \\
\hline & Kandelia & candel Druce & CBES664 & Least Concern \\
\hline \multirow{3}{*}{ Sonneratiaceae } & \multirow{3}{*}{ Sonneratia } & apetala Buch. Ham. & CBES692 & Least Concern \\
\hline & & caseolaris Engler & CBES598 & Not Listed \\
\hline & & griffithii Kurz. & CBES538 & Critically Endangered \\
\hline Combretaceae & Lumnitzera & racemosa Willd. & CBES612 & Least Concern \\
\hline \multirow{3}{*}{ Meliaceae } & \multirow{2}{*}{ Xylocarpus } & granatum Koen & CBES588 & Least Concern \\
\hline & & mekongensis Pieree & CBES476 & Least Concern \\
\hline & Aglaia & cuculata Pellegrin & CBES440 & Data Deficient \\
\hline \multirow{3}{*}{ Avicenniaceae } & \multirow{3}{*}{ Avicennia } & alba Blume & CBES518 & Least Concern \\
\hline & & marina vierh. & CBES432 & Least Concern \\
\hline & & officinalis $\mathrm{L}$. & CBES504 & Least Concern \\
\hline Plumbaginaceae & Aegialitis & rotundifolia Roxb. & CBES621 & Near Threatened \\
\hline Sterculiaceae & Heritiera & fomes Buch. Ham. & CBES556 & Endangered \\
\hline Myrsinaceae & Aegiceras & corniculatum Blanco & CBES484 & Least Concern \\
\hline \multirow{2}{*}{ Palmae/Arecaceae } & Nypa & fruticans Wumb. & CBES579 & Least Concern \\
\hline & Phoenix & paludosa Roxb. & CBES614 & Near Threatened \\
\hline
\end{tabular}



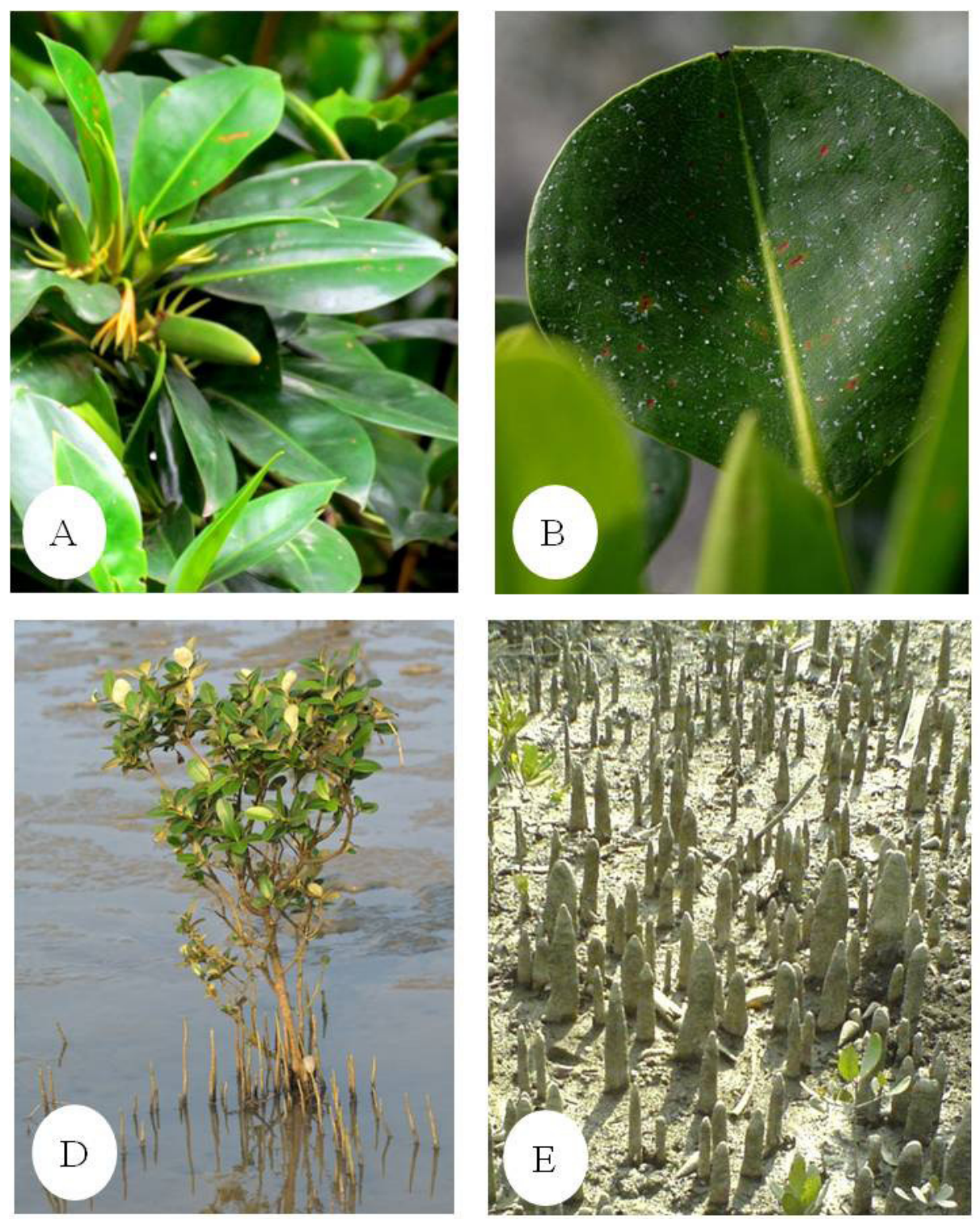
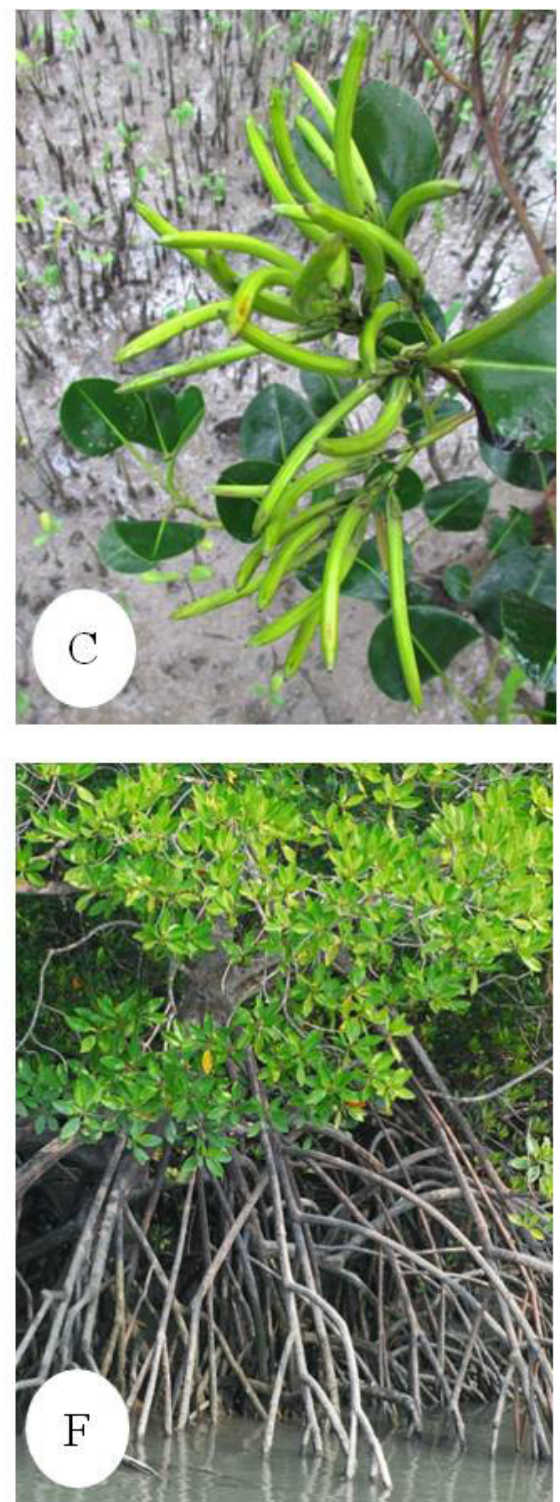
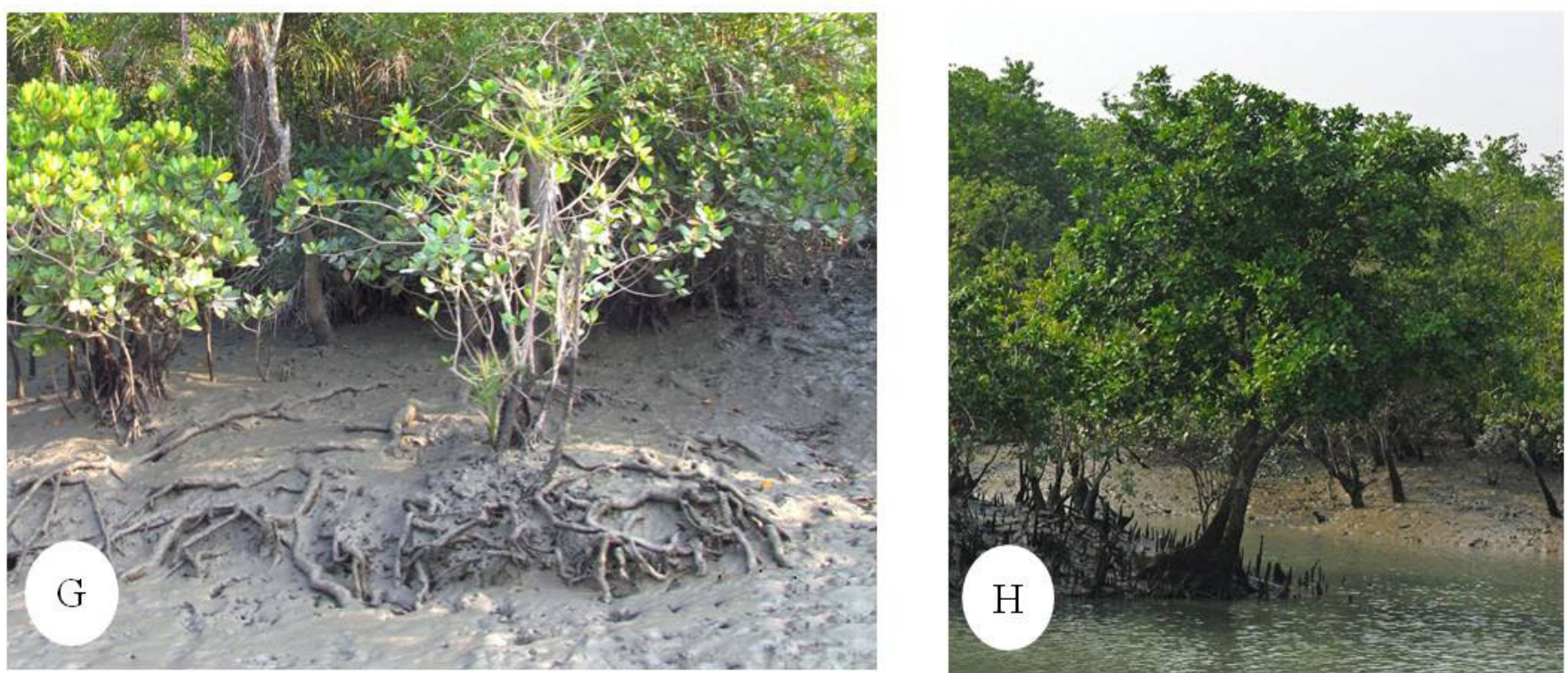

FigURE 5. Representative images of adaptive features for true mangroves in Indian Sundarbans: (a) Succulent leaves of Bruguiera sexangula, (b) Salt crystals on the leaf of Aegialitis rotundifolia, (c) Viviparous germination in A. rotundifolia, (d) Pneumatophores in Avicennia officinalis, (e) Knee roots in Xylocarpus mekongensis, (f) Stilt roots in Rhizophora mucronata, (g) Snake roots in Ceriops decandra, (h) Root buttress in X. mekongensis. 


\section{Literature Cited}

Askornkoae, S., G.S. Maxwell, S. Havanond and S. Panichsuko. 1992. Plants in Mangroves. Bangkok: Chalongrat Co. Ltd. 120 pp.

Banerjee, L.K., T.A. Rao, A.R.K. Shastry and D. Ghosh. 2002. Diversity of Coastal Plant Communities in India. Kolkata: ENVIS-EMCBTAP, Botanical Survey of India, Ministry of Environment and Forests. 524 pp.

Blasco, F. 1977. Outline of ecology, botany and forestry of the mangals of the Indian subcontinent, West Coastal Ecosystems. Oxford: Elsevier Scientific Publishing Company. 241 pp.

Chaudhuri, A.B. and A. Choudhury. 1994. Mangroves of the Sundarbans. Vol. I. India, The IUCN Wetlands Programme. Bangkok: IUCN. 247 pp.

Duke N.C., M.C. Ball and J.C. Ellison 1998. Factors influencing biodiversity and distributional gradients in mangroves. Global Ecology and Biogeography Letters 7: 27-47.

Giesen W., S. Wulffraat, M. Zieren and L. Scholten. 2006. Mangrove Guidebook for Southeast Asia. Bangkok: Rap Publication, Food and Agriculture Organization of the United Nations Regional Office for Asia and the Pacific. 769 pp.

Guha Bakshi, B.N., P. Sanyal, and K.R. Naskar. 1998. Sundarban Mangals. Kolkata: Naya Prakash. 771 pp.

IUCN 2011. The IUCN Red List of Threatened Species. Version 2011.2. Electronic database accessible at http://www.iucnredlist.org. Captured on 2 March 2012.

MacNae, W. 1968. A general account of the fauna and flora of mangrove swamps and forests in the Indowest Pacific region. Advances in Marine Biology 6: 73-270.

Mandal, A.K. and N.C. Nandi. 1989. Fauna of Sundarban Mangrove Ecosystem, West Bengal, India. Fauna of Conservation Areas: 3. Kolkata: Zoological Survey of India. 116 pp.

Mandal R.N. and K.R. Naskar. 2008. Diversity and classification of Indian mangroves: a review. Tropical Ecology 49(2): 131-146.
Mepham, R.H. and J.S. Mepham. 1984. The flora of tidal forests - a rationalization of the use of the term 'mangrove'. South African Journal of Botany 51: 77-99.

Naskar, K.R.1983. Halophytes and their unique adaptations on the Sundarban Mangrove Swamps. Journal of Indian Society for Coastal and Agricultural Research 1(2): 91-105.

Naskar, K.R. and D.N. GuhaBakshi. 1987. Mangrove Swamps of the Sundarbans - An Ecological Perspective. Calcutta: Naya Prakash. 263 pp.

Naskar, K.R. and R.N. Mandal. 1999. Ecology and Biodiversity of Indian Mangroves. New Delhi: Daya Publishing House. 754 pp.

Sengupta, S. and A. Lahiri Majumdar. 2010. Porteresia coarctata (Roxb.) Tateoka, a wild rice: a potential model for studying salt-stress biology in rice. Plant, Cell and Environment 33: 526-542.

Tomlinson, P.B. 1986. The Botany of Mangroves. Cambridge, London, New York: Cambridge University Press. 414 pp.

Umali, R.M., M.A. Eusebio, F.O. Tesoro, H.T. Chan, S. Ibrahim and J.E. Ong 1987. Management Techniques and Methodologies; pp. 471-511, in: R.M. Umali, (ed.). Mangroves of Asia and the Pacific: Status and Management. Manila: Natural Resources Management Centre and National Mangrove Committee, Ministry of Natural Resources.

Untawale, A.G. 1987. Country reports: India; pp. 51-87, in: R.M. Umali, P.M. Zamora, R.R. Gotera, R.S. Jara and A.S. Camecho (ed.). Mangroves of Asia and the Pacific: Status and Management. Manila: Natural Resources Management and National Mangrove Committee, Ministry of Natural Resource.

RECEIVED: September 2013

ACCEPTED: March 2014

Published ONLINE: May 2014

EDITORIAL RESPONSIBILITY: Paul A. Egan 